\title{
Biopreservation of Apricot pulp and Apricot Ready to Serve by using Bacteriocin of Lactobacillus brevis SM6 and their Comparison with Chemical Preservative
}

\author{
Archna Dharwal, Nivedita Sharma*, Shakshi Sharma and Kanika Sharma \\ Department of Basic Sciences (Microbiology), Dr Y S Parmar University of Horticulture and \\ Forestry Nauni- Solan, Himachal Pradesh, India \\ *Corresponding author
}

\section{A B S T R A C T}

\begin{tabular}{|c|}
\hline Keywords \\
\hline $\begin{array}{l}\text { Shelf life, } \\
\text { Antimicrobial } \\
\text { activity, Indicator } \\
\text { bacteria, Pathogens }\end{array}$ \\
\hline Article Info \\
\hline $\begin{array}{l}\text { Accepted: } \\
26 \text { April } 2020 \\
\text { Available Online: } \\
10 \text { May } 2020\end{array}$ \\
\hline
\end{tabular}

Keywords

Shelf life,

Antimicrobial

activity, Indicator

\section{Introduction}

Nature has given many types of foods to the mankind. Everybody expects that the food they eat is wholesome and safe for consumption. The greatest threat to quality and safety of our food comes from the microbial spoilage (Pal, 2013). Preservatives are a type of food additive which are added to food to prolong shelf life, and keep the products from being broken down by microorganisms (Pal, 2014), though chemical preservatives for the preservation of food are successful to some extent, their quality is not
Food safety is a growing public health concern of both in the developing, and developed nations. The consumption of chemically preserved foods raises the concern among the consumer for naturally produced antimicrobial agents. Therefore, in the present study an attempt has been made for the preparation of apricot RTS and apricot plum with bacteriocin Lactobacillus brevis SM6 (crude and purified) and was compared with ard chemical preservative (sodium benzoate) to evaluate the effect of bioand found that bacteriocin of Lactobacillus brevis SM6 was at par with chemical preservative in preserving apricot RTS and apricot pulp efficiently by preventing the growth of spoilage causing pathogens. The effect of bacteriocin was also compared statistically with chemical preservative to prove its efficacy for biopreservation. 
strains. Among biopreservatives, bacteriocin has caught attention of food scientists to be used as a natural food biopreservative due to its antimicrobial activity against serious pathogenic and food spoilage bacteria (Gupta et al., 2015). A high diversity of various bacteriocins is produced by many lactic acid bacteria (LAB) and is found in numerous fermented and non-fermented foods. LAB is used as natural or selected starters in food fermentations in which they perform acidification due to the production of lactic and acetic acids (Gupta and Sharma, 2017). Several bacteriocins from LAB extend potential applications in food preservation, thus help foods to be naturally preserved and richer in organoleptic and nutritional properties. Among biopreservatives, nisin has already been used successfully at commercial scale in dairy products (Sharma and Gautam, 2007). Biopreservation, defined as the extension of shelf life and enhanced safety of foods by the use of natural or controlled microbiota and/or antimicrobial compounds Two approaches of food biopreservation are generally followed:

Direct approach: Addition of bacteriocin to the food product

Indirect approach: Addition of bacteriocinogenic lactic acid bacteria to the food product.

These methodologies of food biopreservation are selected on the basis of many intrinsic and extrinsic factors such as nature of the food product. As in non fermented food products or beverages bacteriocin mediated biopreservation is more productive than the use of cell cultures of probiotics. Since, bacteriocins are bioproducts they do not tend to change the properties of food product such as, its flavor, colour, texture physicochemical properties etc. but their antimicrobial properties tend to eliminate or restrict the pathogenic bacteria thus, enhancing the stability and shelf life of food products. Live bacteriocingenic probiotics can be directly added to food products which can be preserved by fermentation as the probiotics contribute to preservation through production of various antimicrobial compounds. In the present investigation both these methods of biopreservation were applied and their effects were studied. The majority of bacteriocin producers are natural food isolates and hence they are suited for food applications (Raja et al., 2010). Application of bacteriocin may help to reduce the use of chemical preservatives and the intensity of heat and other physical treatments, satisfying the demand of consumers for foods that are fresh in taste, ready to eat and lightly preserved. Moreover, bacteriocins being proteinaceous in nature, once administered in gastrointestinal tract, do not have any residual effect, contrary tochemical preservatives which are highly health hazardous in nature. In the present study, therefore an attempt has been made to study the biopreservative effective of bacteriocin on apricot RTS and apricot pulp prepared and its comparison with the generally used chemical biopreservative (sodium benzoate).

\section{Materials and Methods}

\section{Food biopreservation}

Apricot (Prunus armeniaca L.) RTS beverage and pulp were taken in this study to determine the effect of bio-preservation in them during storage. Each product was treated separately with purified and partially purified bacteriocin of Lactobacillus brevis SM6, chemical preservative sodium benzoate and the bacteriocin producer LAB i.e. Lactobacillus brevis SM6. Purified and partially purified bacteriocin were added @ 5000 AU/ml each and the chemical preservative sodium benzoate was added in concentration of 2000 
ppm. Controls were also run in parallel i.e. food products without any preservative. The products were kept for storage under refrigerated conditions for 30 days. The quality evaluation of the products was done periodically on $0,7,14,21$ and 30 days.

In total 6 sets were made with each product as given below.

\section{Bacteriocin mediated preservation}

SET-A - Control (pasteurized sample) + (pathogen) Listeria monocytogenes $\left(10^{8}\right.$ $\mathrm{CFU} / \mathrm{ml})$

SET-B - Product + (pathogen) Listeria monocytogenes $\left(10^{8} \mathrm{CFU} / \mathrm{ml}\right)+$ Crude bacteriocin $(5000 \mathrm{AU} / \mathrm{ml})$

SET-C - Product + (pathogen) Listeria monocytogenes $\left(10^{8} \mathrm{CFU} / \mathrm{ml}\right)+$ purified bacteriocin $(5000 \mathrm{AU} / \mathrm{ml})$

SET-D - Product + (pathogen) Listeria monocytogenes $\left(10^{8} \mathrm{CFU} / \mathrm{ml}\right)+$ chemical preservative (2000 ppm)

Potential bacteriocinogenic lactic acid bacteria mediated preservation

SET-A - Control (pasteurized sample) + (pathogen) Listeria monocytogenes $\left(10^{8}\right.$ $\mathrm{CFU} / \mathrm{ml})$

SET-E - Product + (pathogen) Listeria monocytogenes $\left(10^{8} \mathrm{CFU} / \mathrm{ml}\right)+$ Lactobacillus brevis SM6 $\left(10^{8} \mathrm{CFU} / \mathrm{ml}\right)$

SET-F - Product + L. monocytogenes $\left(10^{8}\right.$ $\mathrm{CFU} / \mathrm{ml})$

\section{Pulp preparation}

\section{Ingredients}

i. Ripened apricot: $600 \mathrm{~g}$

ii. Water: $200 \mathrm{ml}$

Recipe

Ripened fruits were taken

Fruits were peeled

Peeled fruits were boiled in minimum amount of water for 10 minutes

The fruits were then mashed

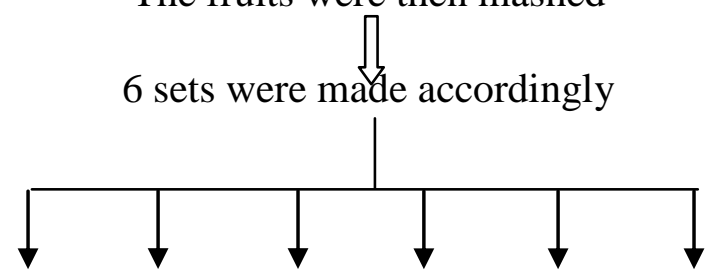

SET A SET B SET C SET D SET E SET F

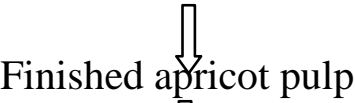

Refrigration at $4^{0} \mathrm{C}$

Evaluation of quality attributes. 


\section{Sensorial evaluation}

Sensorial evaluation of each set was done in terms of appearance, texture, flavor, flavor, odor and overall acceptability. Nine point hedonic scale method as given by Amerine et al., (1965) was followed for conducting the sensory evaluation of the food product.

The panel of 10 judges was selected to evaluate the products for sensory parameters such as appearance, flavor, texture, taste, odor and overall acceptability depending upon the type of product.

Efforts were made to keep the same panel for sensory evaluation throughout the course of study.

\section{Physicochemical changes during storage}

\section{pH}

$\mathrm{pH}$ of each set was measured using $\mathrm{pH}$ meter at an interval of $0,7,14,21$ and 30 days.

\section{Total soluble solids (TSS)}

TSS was measured by placing 1-2 drops of sample on the prism of a hand refractometer. For $0,7,14,21$ and 30 days and the results were expressed as ${ }^{\circ} \beta$ (Ranganna, 2009).

\section{Acidity in terms of lactic acid}

An aliquot of the sample prepared was diluted with recently boiled distilled water. 2-3 drops of $1 \%$ phenolphthelein solution was used as an indicator and titration was done with $0.1 \mathrm{~N}$ $\mathrm{NaOH}$. Titre value was noted and calculations were done as percent anhydrous lactic acid.

\section{Ascorbic acid}

Ascorbic acid was determined as per AOAC (1995) method for 0, 7, 14, 21 and 30 days.

\section{Total carbohydrates}

Total carbohydrates were determined as per Sadasivam and Manickam (1992).

\section{Total proteins}

Total proteins were determined by following the method given by Ranganna (2009).

\section{Crude fibers}

Crude fibers were determined as per the method described in AOAC (1995).

Free radical scavenging activity (FRSA) (Brand et al., 1995)

Free radical scavenging activity was measured as per the method of Brand et al., (1995). DPPH (2, 2-diphenyl-1picrylhydrazyl) was used as a source of freeradical.

\section{Microbial study during storage}

The colony count was observed during storage period of $0,7,14,21$ and 30 days by standard spread plate count method. MRS agar was used to enumerate lactic acid bacteria while nutrient agar was used to enumerate Listeria monocytogenes.

\section{Statistical analysis}

Data pertaining to the physicochemical attributes and data on sensorial evaluation of prepared food product (apricot RTS) was analyzed by completely randomized design (CRD) factorial as described by O'Mahony and Decker (1985).

\section{RTS preparation}

\section{Ingredients}

Apricot pulp: $60 \mathrm{~g}$

Sugar: $52.8 \mathrm{~g}$

Water: $545.16 \mathrm{ml}$

Acid: $1.56 \mathrm{~g}$ 


\section{Recipe}

Apricot (pulp/juice)

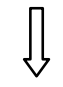

Mixing with strained syrup solutions (sugar+water+acid in quantities as mentioned above)

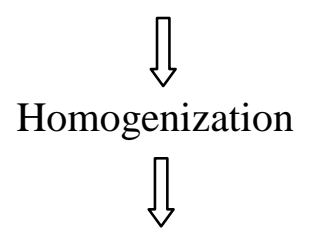

Bottling (100 $\mathrm{ml}$ in each bottle)<smiles>[CH]=C</smiles>

Corking<smiles>[CH]=C</smiles>

Pasteurization (at $90^{\circ} \mathrm{C}$ for $25 \mathrm{~min}$ )<smiles>C=CC=C</smiles>

Cooling (to room temperature)<smiles>[CH]=C</smiles>

Treatments (6 Sets were made accordingly)

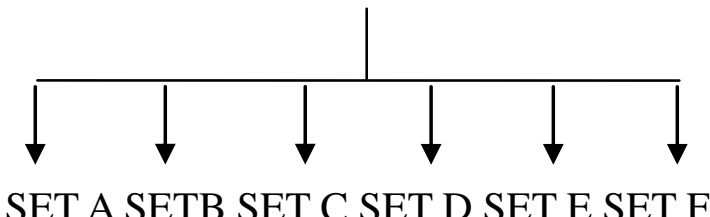

SET A SETB SET C SET D SET E SET F

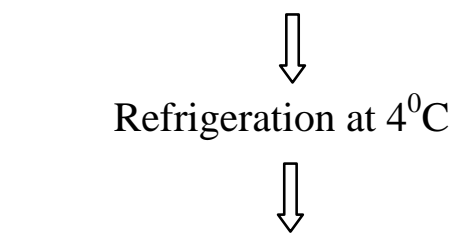

Evaluation of quality attributes

\section{Sensorial evaluation}

Sensorial evaluation of each set was done in terms of appearance, texture, flavor, flavor, odor and overall acceptability as given by Amerine et al., (1965)

\section{Physicochemical changes during storage}

The physiological changes i.e. $\mathrm{pH}$, total proteins, total carbohydrates and crude fibers were performed as mentioned in section 2.2.4.

\section{Microbial study during storage}

The microbial study was done same as mentioned in section 2.2.5

Statistical analysis: was done according to the method described by O'Mahony and Decker (1985). 


\section{Results and Discussion}

In the present study, apricot RTS and apricot plum preparations with bacteriocin (crude and purified) was compared with standard chemical preservative (sodium benzoate) to evaluate the effect of bio-preservation in the food and a negative control was run along with these to detect the efficacy of the preservative. The food products selected for experiment were kept for 30 days and the effect was noted at 0,7 th, 14th, 21st and 30th day. The chemical preservative was added at permissible limits i.e. 2000 ppm. The bacteriocin activity which was found to be $8000 \mathrm{AU} / \mathrm{ml}$ and $6000 \mathrm{AU} / \mathrm{ml}$ in case of purified and partially purified bacteriocin was kept at $5000 \mathrm{AU} / \mathrm{ml}$ (Ray et al., 2001).

\section{Prunus armeniaca L. (Apricot)}

Apricot (Prunus armeniaca L.) is a very important stone fruit of temperate as well as mid hills of Himachal Pradesh. The fruit has a nutritional value of interest having a good source of fiber, minerals (especially potassium but also calcium, iron, magnesium, zinc, phosphorus and selenium) and vitamins such as vitamin $\mathrm{A}$, vitamin $\mathrm{C}$, thiamin, riboflavin, niacin and pantothenic acid. The total mineral content of the pulp, as represented by its ash, is $2.452 \%$. The percentage content of different mineral elements in the pulp is phosphorus, 0.083; potassium, 0.996 ; calcium, 0.042 ; magnesium, 0.033; and iron, 0.010. The protein is only 0.67 per cent. Dry matter in apricot is about $10-20 \%$; main constituents are sugar, polysaccharides and organic acids (Belitz et al., 2009). Fruits contain 0.1-1.5\% nitrogen compounds; $35-75 \%$ of these nitrogen compounds are proteins. Free amino acids are also abundant. Moreover, apricots contain a number of main secondary metabolites such as polyphenols, carotenoids, fatty acids, volatiles and polysaccharides. In particular, phenolic compounds are one of the main sources of antioxidant activity which are able to prevent oxidative stress scavenging free radicals and nitrogen species (Erdogan and Kartal, 2011).

\section{Apricot pulp}

Apricot pulp was prepared as per the method given by Rangana (2009). The ingredients required were- ripened apricot $(600 \mathrm{~g})$ and water $(150 \mathrm{ml})$. First of all the ripened fruits were taken and peeled. Peeled fruits were then boiled in minimum amount of water for $10 \mathrm{~min}$ and were then mashed. Different treatments were then applied accordingly as described above. All the sets were kept for 1 month for further evaluation. Nutritional facts of fresh apricot pulp without any fortification has been presented in Table 1 .

Sets: In total 6 sets were made

Direct approach: Bacteriocin mediated

SET-A - Product + L. monocytogenes $\left(10^{8} \mathrm{CFU} / \mathrm{ml}\right)$

SET-B - Product + L. monocytogenes $\left(10^{8}\right.$ $\mathrm{CFU} / \mathrm{ml})+$ Crude bacteriocin $(5000 \mathrm{AU} / \mathrm{ml})$ SET-C - Product + L. monocytogenes $\left(10^{8} \mathrm{CFU} / \mathrm{ml}\right)+$ purified bacteriocin (5000 AU/ml)

SET-D - Product + L. monocytogenes $\left(10^{8} \mathrm{CFU} / \mathrm{ml}\right)+$ chemical preservative (2000ppm)

Indirect approach: Bacteriocinogenic bacteria mediated

SET-A - Product + L. monocytogenes $\left(10^{8}\right.$ $\mathrm{CFU} / \mathrm{ml}$ )

SET-E - Product + L. monocytogenes $\left(10^{8}\right.$ $\mathrm{CFU} / \mathrm{ml})+$ L. brevis SM6 $\quad\left(10^{8} \mathrm{CFU} / \mathrm{ml}\right)$ SET-F - Product + L. brevis SM6 $\left(10^{8}\right.$ $\mathrm{CFU} / \mathrm{ml}$ )

To study the effects at experimental level 25 $\mathrm{ml}$ of product was taken in separate tubes 
(Fig. 1 a $\&$ b) to which the preservatives were added accordingly. Each set contained $25 \mathrm{ml}$ pulp and $1 \mathrm{ml}\left(10^{8} \mathrm{CFU} / \mathrm{ml}\right) \quad L$. monocytogenes was added to each set to desirably cause spoilage and to study the effects of various treatments. Crude bacteriocin $(20.75 \mathrm{ml})$ was added to set $\mathrm{B}$ and purified bacteriocin $(15.63 \mathrm{ml})$ was added to set $C$. Further evaluation of all the sets was done periodically for one month.

\section{Sensorial evaluation}

Freshly prepared apricot pulp samples were assessed by 10 panelists using a 9 point sensory hedonic scale for some sensory parameters (viz. appearance, flavor, texture, taste and overall acceptability), as described by Amerine et al., (1965). In a sensory evaluation set A was least accepted (with overall acceptability 4.94) whereas set $\mathrm{C}$ had a maximum acceptability (8.42) (Fig. 2). Statistically sensorial evaluation was carried out by Completely Randomized Design (CRD). The results showed a significant effect of different treatments on sensory attributes of apricot pulp and also indicate that the type of bacterial strain contributes a significant influence on the overall acceptability of the product. Castro et al., (2017) did sensory evaluation of banana pulp in terms of colour, texture, flavor, taste, odor and overall acceptability.

\section{Microbiological study of apricot pulp}

During biopreservation studies it was noticed that control (i.e. without addition of bacteriocin) has shown rapid growth of $L$. monocytogenes leading to spoilage within three days of product formulation. On the other hand crude bacteriocin (Set B) has created the preservative effect till $7^{\text {th }}$ day while purified bacteriocin (Set C) and chemical preservatives (Set D) were found the most efficient to check the growth of $L$. monocytogenes and keeping the product preserved till $30^{\text {th }}$ day with the meager increase in L. monocytogenes $\log \mathrm{CFU} / \mathrm{ml}$ i.e. 4.50 and 5.99 respectively. This experiment proves that purified bacteriocin is capable of preserving apricot pulp efficiently.

In case of direct addition of bacteriocinogenic $\mathrm{LAB}$ it was found that $\mathrm{LAB}$ number started decreasing gradually from $7^{\text {th }}$ day (log $\mathrm{CFU} / \mathrm{ml}$ 4.85) onwards upto 30 days (2.80 log $\mathrm{CFU} / \mathrm{ml}$ ) in the product probably due to unfavourable environment. The preservation effect of bacteriocin produced by $L$. brevis OG1 was evaluated by Ogunbanwo and Okanlawon (2006), for chicken immobilized inedible films. $L$ brevis OG1 produce bacteriocin that has a broad spectrum of inhibition against pathogens and food spoilage organisms created during storage as evident from physicochemical parameters (pH, TSS, TA, ascorbic acid). As far as growth of L. monocytogenes is concerned in these products biopreservative effect was observed with minimal increase in their log CFU/ml i.e. 4.90 (0 day) to $5.15\left(30^{\text {th }}\right.$ day) (Fig. $3 \& 4$ ). The biopreservative effect in this case is due to different antimicrobial compounds secreted by L. brevis SM6 in this culture medium (lactic acid, $\mathrm{H}_{2} \mathrm{O}_{2}$, acetic acid alongwith bacteriocin). Upon comparison between direct and indirect approach, it is clear that addition of purified bacteriocin is the best option for food biopreservation probably because of its powerful antagonistic potential expressed i.e. $8000 \mathrm{AU} / \mathrm{ml}$ present in it. Addition of bacteriocin/ bacteriocinogenic LAB for food preservation is preferred according to the nature of the food products as many intrinsic and extrinsic parameters affect food processing and preservation, e.g. in non-fermented refrigerated products only purified or semipurified bacteriocin preparations are applied for preservation rather than applying cell culture. The direct addition of purified 
bacteriocin provides a more controlled preservative tool in such products. Furthermore, bacteriocin producing cells of lactic acid bacteria having probiotic potential are also added in food products which can be preserved by means of fermentation. These lactic acid bacteria contribute in preservation, as during preservation these will produce different antimicrobial compounds such as lactic acid, acetic acid, hydrogen peroxide, carbon dioxide besides bacteriocins which altogether inhibit pathogenic and spoilage causing microorganisms, extending their shelf life and enhancing the safety of food products.

Ogunbanwo and Okanlawon (2006), observed that immobilization of bacteriocin produced by $L$. brevis OG1 in calcium alginate gel and application to the surfaces of lean tissue (cutaneous) of broiler chicken was effective for reducing microbial load up to 21 days of refrigerated storage.

\section{Changes inquality attributes of apricot pulp during storage}

Prepared apricot pulp samples were kept for storage for 30 days and the quality attributes $(\mathrm{pH}$, total soluble solid, titratable acidity and ascorbic acid) of each set were noted on $0,7^{\text {th }}$, $14^{\text {th }}, 21^{\text {st }}$ and $30^{\text {th }}$ days of storage as described in Table 2. $\mathrm{pH}$ followed the same trends as apricot RTS, it was observed that the $\mathrm{pH}$ values slightly decreased during the storage. On $30^{\text {th }}$ day maximum decrease was noticed in set A (2.56) and minimum in set C (3.33). Total soluble solid of apricot RTS remained almost same for sets $A$ to $E$ but there was decrease in TSS in Set F $\left(11.12^{0} B\right)$.

Initially TSS values were same for all sets $\left(12^{0} B\right)$. After 30 days TSS was maximum for set $A$ and minimum for set $\mathrm{H}$. Titratable acidity was measured in terms of lactic acid. Titratable acidity is negatively correlated with
$\mathrm{pH}$ that means while $\mathrm{pH}$ decreased, titratable acidity increased. The initial lactic acid was $0.45 \%$ for every RTS set. On $30^{\text {th }}$ day of storage lactic acid \% had increased most in set $\mathrm{F}$ to $0.96 \%$ and was at par in case of set $\mathrm{C}$ and D (0.91). Ascorbic acid content of apricot pulp also showed variation in its values during storage period. Initially ascorbic acid content ranges in between 9.85 to $9.88 \mathrm{mg} / \mathrm{ml}$ in all sets which rose in every treatment. Statistically changes in quality attributes of apricot during storage period were analyzed by CRD factorial which revealed that there are non-significant results of change in quality attributes of apricot RTS during storage conditions.

\section{Apricot Ready to Serve (RTS) beverage}

$80 \mathrm{~g}$ apricot pulp was taken which was mixed in strained sugar syrup (containing 70. $4 \mathrm{~g}$ sugar and $647.52 \mathrm{ml}$ water) and was properly homogenized. Bottling of the product $(100 \mathrm{ml}$ in each bottle) was done, and the bottles were properly corked which were then pasteurized at $90^{\circ} \mathrm{C}$ for $25 \mathrm{~min}$. They were left for cooling at room temperature and the treatments were applied accordingly. Nutritional facts of fresh apricot RTS without any fortification has been presented in Table 3 .

Sets: In total 6 sets were made

Direct approach: Bacteriocin mediated

SET-A - Product + L. monocytogenes $\left(10^{8}\right.$ $\mathrm{CFU} / \mathrm{ml}$ )

SET-B - Product + L. monocytogenes $\left(10^{8}\right.$ $\mathrm{CFU} / \mathrm{ml})+$ crude bacteriocin $(5000 \mathrm{AU} / \mathrm{ml})$ SET-C - Product + L. monocytogenes $\left(10^{8}\right.$ $\mathrm{CFU} / \mathrm{ml})+$ purified bacteriocin (5000 $\mathrm{AU} / \mathrm{ml}$ )

SET-D - Product + L. monocytogenes $\left(10^{8}\right.$ $\mathrm{CFU} / \mathrm{ml})+$ chemical preservative $\quad(2000$ ppm)

Indirect approach: Bacteriocinogenic bacteria mediated

SET-A - Product + L. monocytogenes $\left(10^{8}\right.$ 
$\mathrm{CFU} / \mathrm{ml})$

SET-E - Product + L. monocytogenes $\left(10^{8}\right.$ $\mathrm{CFU} / \mathrm{ml})+$ L. brevis SM6 $\quad\left(10^{8} \mathrm{CFU} / \mathrm{ml}\right)$ SET-F - Product + L. brevis SM6 $\left(10^{8}\right.$ $\mathrm{CFU} / \mathrm{ml})$

To study the effects at experimental level 25 $\mathrm{ml}$ of product was taken in separate tubes (Plate) to which the preservatives were added accordingly (Fig. $5 \mathrm{a} \& b$ ). Each set contained $25 \mathrm{ml} \mathrm{RTS}$ and $1 \mathrm{ml}$ of L. monocytogenes $\left(10^{8} \mathrm{CFU} / \mathrm{ml}\right)$ was added to each set to desirably cause spoilage and to study the effects of various treatments. Crude bacteriocin $(20.75 \mathrm{ml})$ was added to set $\mathrm{B}$ and purified bacteriocin $(15.63 \mathrm{ml})$ was added to set C. Further evaluation of all the sets was done periodically for one month.

\section{Sensorial evaluation}

Freshly prepared apricot RTS samples were assessed by 10 panelists using a 9 point sensory hedonic scale for some sensory parameters (viz. appearance, texture, taste, odor and overall acceptability), as described by Amerine et al., (1965). In sensory evaluation set A was least accepted (with overall acceptability of 5.05), set $\mathrm{C}$ had a maximum acceptability (8.46 out of 10 ) and set $\mathrm{B}$ and set $\mathrm{D}$ were almost equally acceptable (8.08 and 7.92 respectively) (Fig. 6). The results showed a significant effect of different treatments on sensory attributes of apricot RTS and also indicate that the type of bacterial strain contributes a significant influence on the overall acceptability of the product. Dambalkar et al., (2015) performed sensory evaluation of Beetroot orange RTS drink which was accessed in terms of colour, flavor, texture, taste and overall acceptability. A sensory evaluation of carrot juice supplement with the L. acidophilus DSM 20079 was carried out by Goderska et al., (2007) and they found that bacterial strain exerts a significant influence on the sensory evaluation of the examined product.

\section{Microbiological study of apricot RTS}

During biopreservation studies it was noticed that control (i.e. without addition of bacteriocin) has shown rapid growth of $L$. monocytogenes leading to spoilage within three days of product formulation. On the other hand crude bacteriocin (Set B) has created the preservative effect till $7^{\text {th }}$ day while purified bacteriocin (Set C) and chemical preservatives (Set D) were found the most efficient to check the growth of $L$. monocytogenes and keeping the product preserved till $30^{\text {th }}$ day with the meager increase in L. monocytogenes $\log \mathrm{CFU} / \mathrm{ml}$ i.e. 4.57 and 5.78 respectively. This experiment proves that purified bacteriocin is capable of preserving apricot RTS efficiently.

In case of direct addition of bacteriocinogenic $\mathrm{LAB}$ it was found that $\mathrm{LAB}$ number started decreasing gradually from $7^{\text {th }}$ day (log $\mathrm{CFU} / \mathrm{ml} 4.55)$ onwards upto 30 days (2.32 log $\mathrm{CFU} / \mathrm{ml}$ ) in the products probably due to unfavourable environment created during storage as evident from physicochemical parameters (pH, TSS, TA, ascorbic acid). As far as growth of $L$. monocytogenes is concerned in these products biopreservative effect was observed with minimal increase in their $\log \mathrm{CFU} / \mathrm{ml}$ i.e. 4.85 (0 day) to 5.75 $\left(30^{\text {th }}\right.$ day) (Fig. $\left.7 \& 8\right)$. The biopreservative effect in this case is due to different antimicrobial compounds secreted by $L$. brevis SM6 in this culture medium (lactic acid, $\mathrm{H}_{2} \mathrm{O}_{2}$, acetic acid along with bacteriocin). Upon comparison between direct and indirect approach, it is clear that addition of purified bacteriocin is the best option for food biopreservation probably because of its powerful antagonistic potential expressed i.e. $8000 \mathrm{AU} / \mathrm{ml}$ present in it. Addition of bacteriocin/bacteriocinogenic LAB for food preservation is preferred according to the nature of the food products as many intrinsic and extrinsic parameters affect food processing and preservation, e.g. in non- 
fermented refrigerated products only purified or semi-purified bacteriocin preparations are applied for preservation rather than applying cell culture. The direct addition of purified bacteriocin provides a more controlled preservative tool in such products. Furthermore, bacteriocin producing cells of lactic acid bacteria having probiotic potential are also added in food products which can be preserved by means of fermentation. These lactic acid bacteria contribute in preservation, as during preservation these will produce different antimicrobial compounds such as lactic acid, acetic acid, hydrogen peroxide, carbon di oxide besides bacteriocins which altogether inhibit pathogenic and spoilage causing microorganisms, extending their shelf life and enhancing the safety of food products.

\section{Changes in quality attributes of apricot RTS during storage}

Prepared apricot RTS samples were kept for storage for 30 days and the quality attributes $(\mathrm{pH}$, total soluble solid, titratable acidity and ascorbic acid) of each set were noted on $0,7^{\text {th }}$, $14^{\text {th }}, 21^{\text {st }}$ and $30^{\text {th }}$ days of storage as described in Table 4. It was observed that the $\mathrm{pH}$ values slightly decreased during the storage. On $30^{\text {th }}$ day maximum decrease was noticed in set $\mathrm{A}$ and minimum in set E. Total soluble solid of apricot RTS remained almost same for sets A to $\mathrm{E}$ but there was significant decrease in TSS in Set A $\left(9.19^{0}\right.$ B). Initially all sets had a TSS of $10^{0} \mathrm{~B}$ during storage for 30 days. Titratable acidity was measured in terms of lactic acid. Titratable acidity is negatively correlated with $\mathrm{pH}$ that means while $\mathrm{pH}$ decreased, titratable acidity increased. The initial lactic acid was measured to be $0.15 \%$ (Rangana, 2009) for every RTS set. On $30^{\text {th }}$ day of storage lactic acid \% had increased most in set $\mathrm{A}$ and was minimum in case of set $\mathrm{C}(0.66 \%)$ where it remained same. Ascorbic acid content of apricot RTS also showed variation in its values during storage period. Initially ascorbic acid content was found to be 9.5 $\mathrm{mg} / \mathrm{ml}$ (Rangana, 2009) in all sets which increased in every treatment. Statistically changes in quality attributes of apricot during storage period were analysed by CRD factorial which revealed that there is nonsignificant change in results of quality attributes of apricot RTS during storage conditions. The use of L. brevis SM6 for the biopreservation of apricot RTS and apricot pulp proved to be more effective against the spoilage causing pathogens as compared to the chemical preservative (Sodium benzoate) used. Thus, successfully fulfilling the main objective of this study.

Table.1 Nutritional chart of apricot pulp

\begin{tabular}{|l|c|c|c|c|c|c|}
\hline Nutritional facts per 100 ml & \multicolumn{7}{|c|}{ Samples } \\
\cline { 2 - 7 } & SET A & SET B & SET C & SET D & SET E & SET F \\
\hline *Antioxidant activity (\%) & 45.50 & 45.51 & 45.50 & 45.51 & 45.51 & 45.50 \\
\hline *Protein (g/ 100 g) & 1.4 & 1.41 & 1.42 & 1.41 & 1.41 & 1.40 \\
\hline *Fiber (\%) & 3.30 & 3.31 & 3.30 & 3.30 & 3.31 & 3.30 \\
\hline *Carbohydrate (g/ 100 g) & 12 & 11.9 & 12 & 12 & 11.9 & 12.1 \\
\hline *Total sugars (\%) & 9.47 & 9.48 & 9.48 & 9.47 & 9.47 & 9.46 \\
\hline
\end{tabular}

*values evaluated in lab 
Table.2 Physicochemical characteristics of apricot pulp

\begin{tabular}{|c|c|c|c|c|c|c|c|c|c|c|c|c|c|c|c|c|c|c|c|c|c|c|c|c|}
\hline \multirow{3}{*}{$\begin{array}{l}\text { Treatments } \\
\text { (T) }\end{array}$} & \multicolumn{6}{|l|}{$\mathbf{p H}$} & \multicolumn{6}{|c|}{ TSS $\left({ }^{\circ}\right.$ Brix) } & \multicolumn{5}{|c|}{ Titratable acidity (\%) } & \multicolumn{7}{|c|}{ Ascorbic acid (mg/100g) } \\
\hline & \multicolumn{24}{|c|}{ Storage interval (days) } \\
\hline & $\mathbf{0}$ & 7 & 14 & 21 & 30 & Mean & $\mathbf{0}$ & 7 & 14 & 21 & 30 & Mean & $\mathbf{0}$ & 7 & 14 & 21 & 30 & Mean & $\mathbf{0}$ & 7 & 14 & 21 & 30 & Mean \\
\hline Set A & 4.40 & 4.30 & 3.12 & 3.01 & 2.56 & 3.47 & 12.0 & 12.0 & 11.51 & 11.34 & 11.22 & 11.61 & 0.45 & 0.69 & 0.75 & 0.85 & 0.95 & 0.73 & 9.86 & 9.82 & 9.73 & 9.60 & 9.47 & 9.69 \\
\hline Set B & 4.41 & 4.35 & 4.27 & 4.19 & 3.16 & 4.07 & 12.0 & 12.0 & 11.77 & 11.66 & 11.37 & 11.76 & 0.45 & 0.57 & 0.60 & 0.67 & 0.92 & 0.78 & 9.87 & 9.74 & 9.62 & 9.55 & 9.51 & 9.65 \\
\hline Set C & 4.41 & 4.31 & 4.24 & 4.14 & 3.33 & 4.06 & 12.0 & 12.0 & 11.84 & 11.72 & 11.57 & 11.82 & 0.45 & 0.57 & 0.69 & 0.75 & 0.91 & 0.81 & 9.88 & 9.81 & 9.75 & 9.68 & 9.45 & 9.71 \\
\hline Set D & 4.41 & 4.34 & 4.22 & 4.13 & 3.10 & 4.10 & 12.0 & 12.0 & 11.74 & 11.53 & 11.46 & 11.74 & 0.45 & 0.58 & 0.66 & 0.76 & 0.91 & 0.81 & 9.85 & 9.76 & 9.67 & 9.60 & 9.57 & 9.69 \\
\hline Set E & 4.40 & 4.03 & 3.77 & 3.45 & 3.24 & 3.79 & 12.0 & 12.0 & 11.66 & 11.56 & 11.41 & 11.72 & 0.45 & 0.76 & 0.80 & 0.85 & 0.93 & 0.75 & 9.86 & 9.74 & 9.67 & 9.53 & 9.45 & 9.65 \\
\hline Set F & 4.41 & 4.12 & 3.84 & 3.40 & 3.21 & 3.79 & 12.0 & 12.0 & 11.64 & 11.21 & 11.12 & 11.59 & 0.45 & 0.54 & 0.83 & 0.89 & 0.96 & 0.73 & 9.88 & 9.76 & 9.64 & 9.50 & 9.42 & 9.64 \\
\hline Mean & 4.40 & 4.24 & 3.91 & 3.72 & 3.10 & & 12 & 12 & 11.69 & 11.50 & 11.35 & & 0.45 & 0.61 & 0.72 & 0.79 & 0.93 & & 9.86 & 9.77 & 9.68 & 9.57 & 9.47 & \\
\hline $\mathrm{CD}_{0.05}$ & \multicolumn{4}{|c|}{$\begin{array}{l}\text { Treatments }(\mathrm{T}) \\
\text { Storage interval }(\mathrm{S}) \\
\mathrm{T} \times \mathrm{S}\end{array}$} & $\begin{array}{l}0.30 \\
0.31 \\
0.59\end{array}$ & & \multicolumn{3}{|c|}{$\begin{array}{l}\text { Treatments }(\mathrm{T}) \\
\text { Storage interval (S) } \\
\text { T x S }\end{array}$} & \multicolumn{2}{|c|}{$\begin{array}{l}0.19 \\
0.21 \\
0.41\end{array}$} & & \multicolumn{4}{|c|}{$\begin{array}{l}\text { Treatments }(\mathrm{T}) \\
\text { Storage interval }(\mathrm{S}) \\
\mathrm{T} \times \mathrm{S}\end{array}$} & $\begin{array}{l}0.02 \\
0.01 \\
0.03\end{array}$ & & \multicolumn{4}{|c|}{$\begin{array}{l}\text { Treatments }(\mathrm{T}) \\
\text { Storage interval }(\mathrm{S}) \\
\mathrm{T} \times \mathrm{S}\end{array}$} & $\begin{array}{l}0.33 \\
0.36 \\
0.49\end{array}$ & \\
\hline
\end{tabular}

Table.3 Nutritional chart of apricot RTS

\begin{tabular}{|c|c|c|c|c|c|c|}
\hline \multirow[t]{2}{*}{ Nutritional facts per $100 \mathrm{ml}$} & \multicolumn{6}{|c|}{ Samples } \\
\hline & SET A & SET B & SET C & SET D & SET E & SET F \\
\hline *Antioxidant activity (\%) & 4.10 & 4.11 & 4.10 & 4.10 & 4.11 & 4.12 \\
\hline *Protein $(\mathrm{g} / 100 \mathrm{ml})$ & 0.10 & 0.10 & 0.11 & 0.10 & 0.10 & 0.11 \\
\hline$*$ Fiber $(\%)$ & 0.30 & 0.31 & 0.31 & 0.30 & 0.29 & 0.30 \\
\hline *Carbohydrate (g/ 100g) & 11 & 10.9 & 11 & 10.9 & 10.8 & 10.9 \\
\hline *Total sugars (\%) & 3.03 & 3.04 & 3.03 & 3.04 & 3.03 & 3.03 \\
\hline
\end{tabular}

*values evaluated in lab 
Table.4 Physicochemical characteristics of apricot RTS

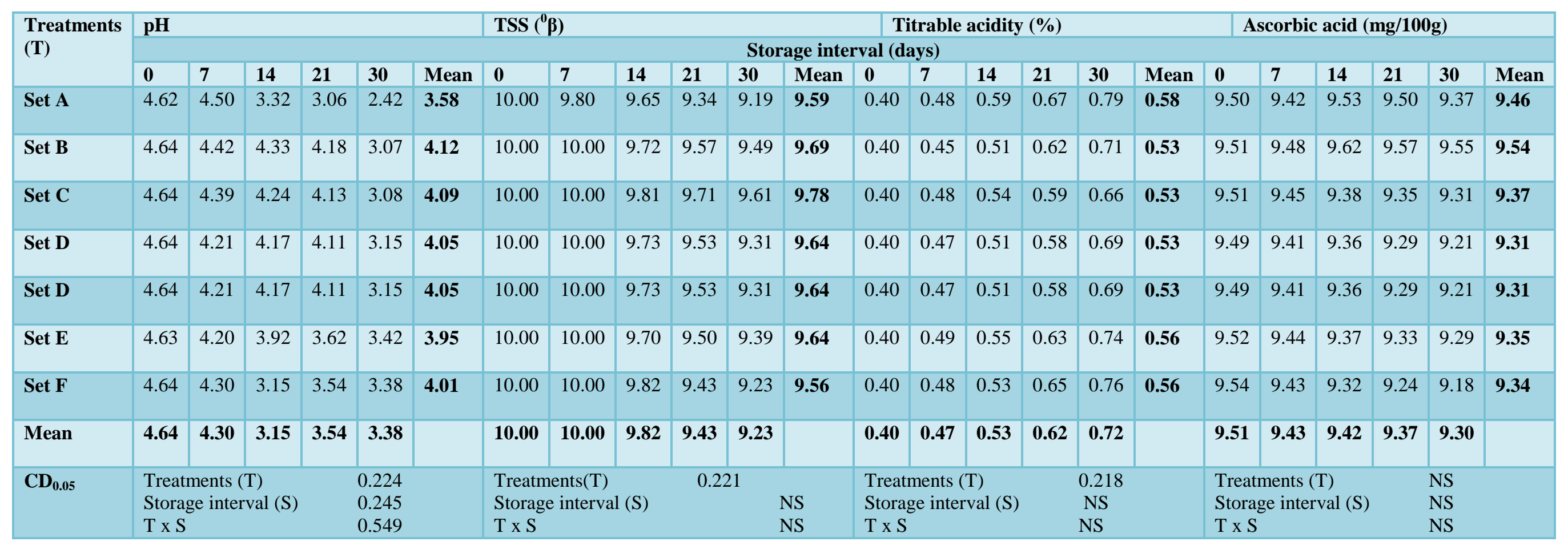


Fig.1 (a \& b) Biopreservation of apricot pulp by purified bacteriocin produced by Lactobacillus brevis SM6

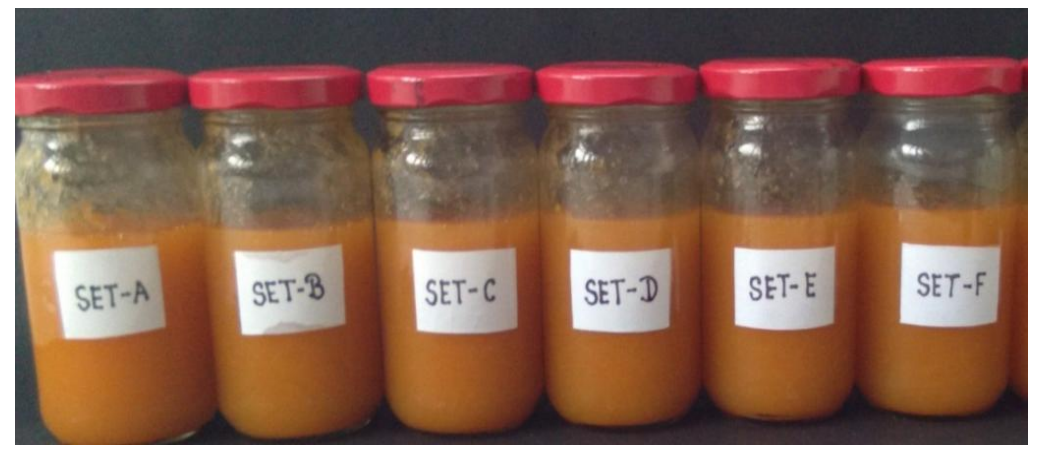

a

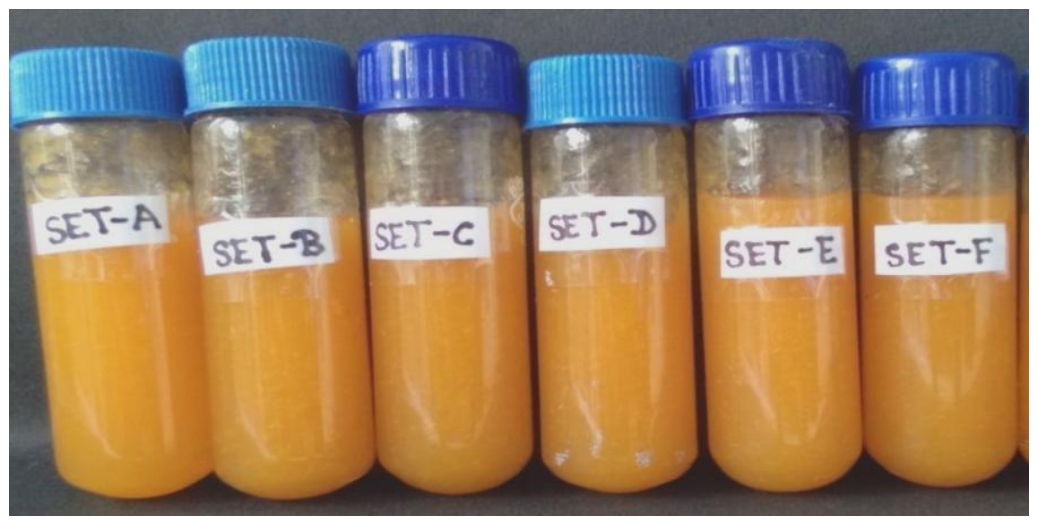

b

Fig.2 Sensorial evaluation of apricot pulp

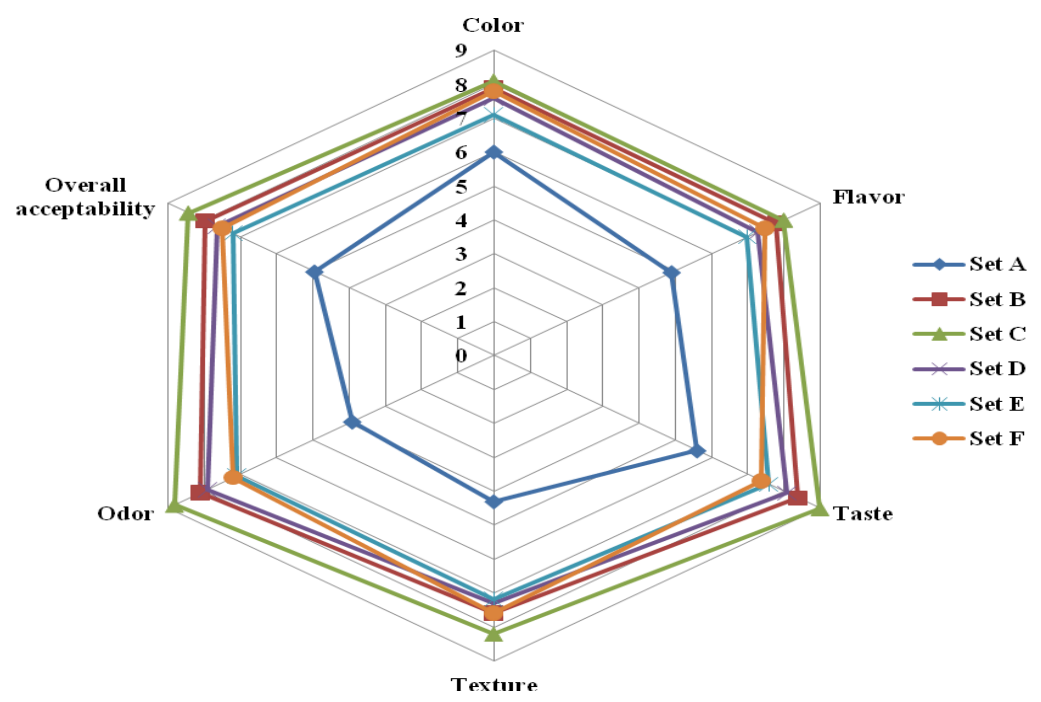


Fig.3 Comparison of crude and purified bacteriocin of Lactobacillus brevis SM6 with chemical preservative against Listeria monocytogenes to enhance shelf life of apricot pulp

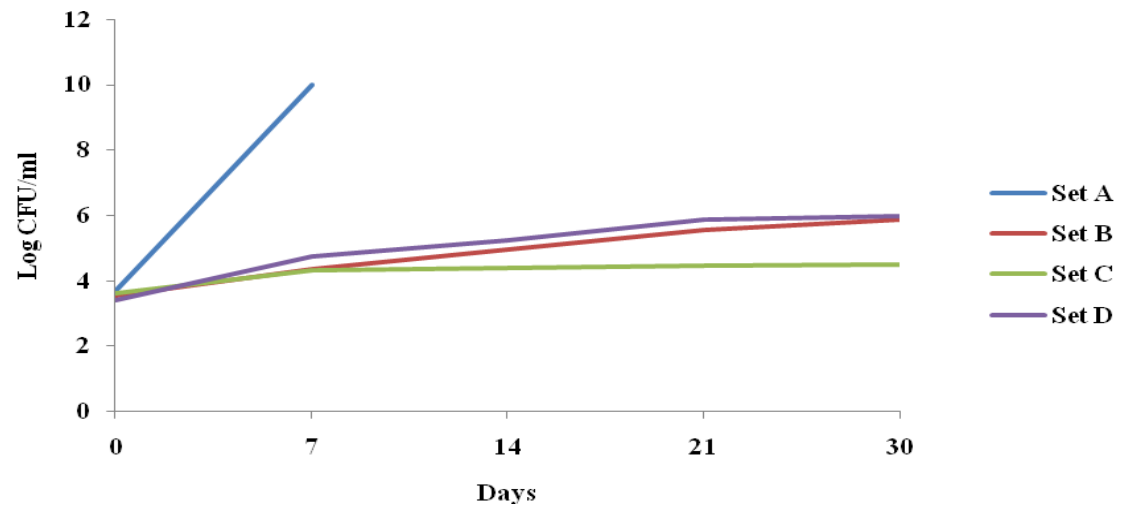

Fig.4 Comparison of Lactobacillus brevis SM6 against Listeria monocytogenes to enhance shelf life of apricot pulp

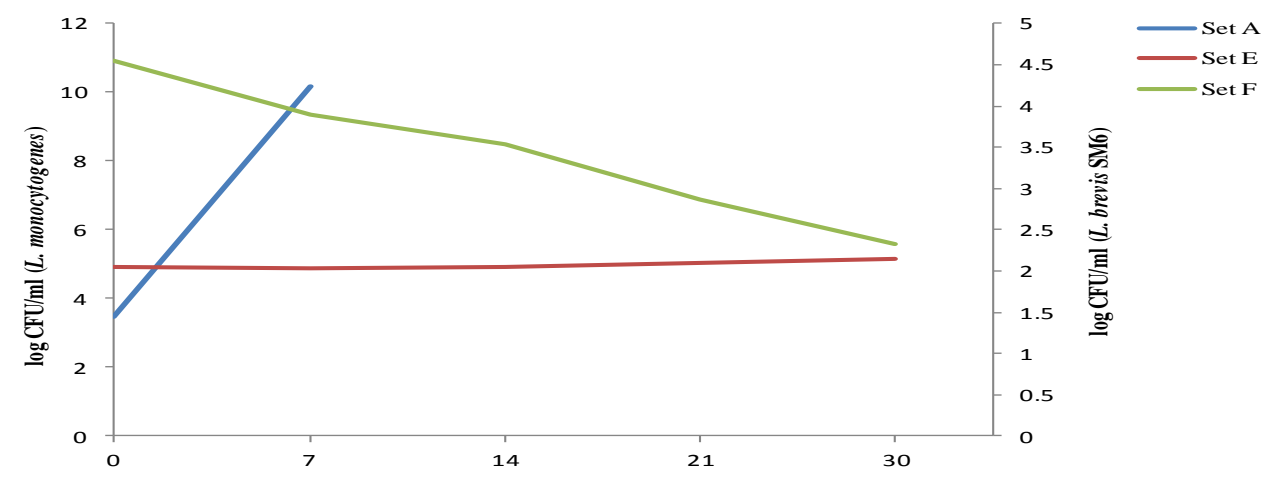

Fig.5 (a\&b) Biopreservation of apricot RTS by purified bacteriocin produced by Lactobacillus brevisSM6

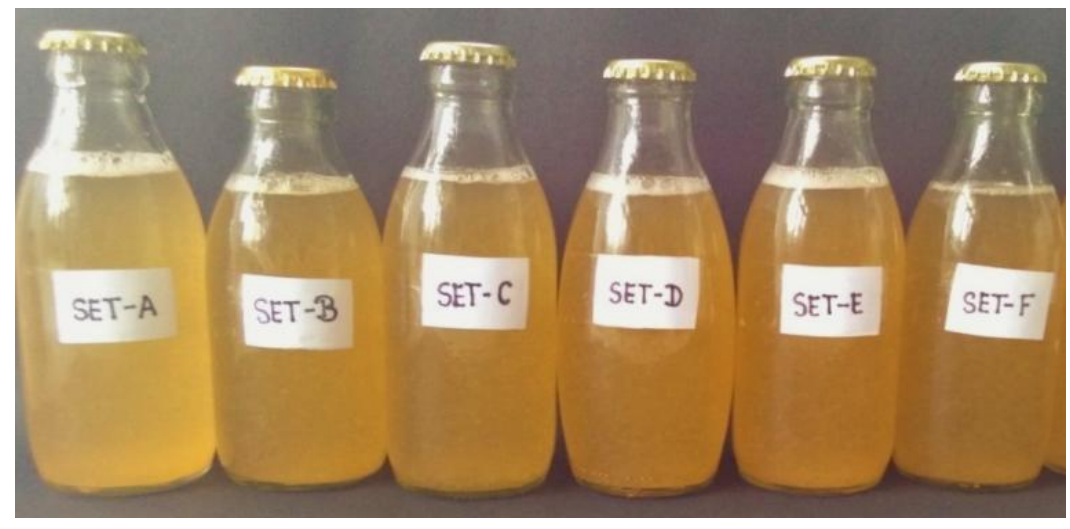

$\mathbf{a}$ 


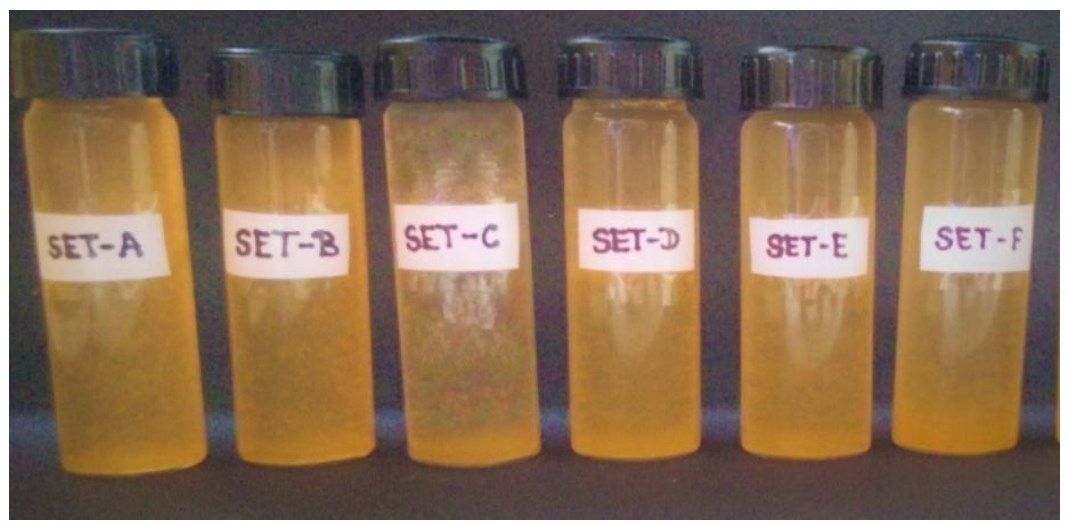

B

Fig.6 Sensorial evaluation of apricot RTS

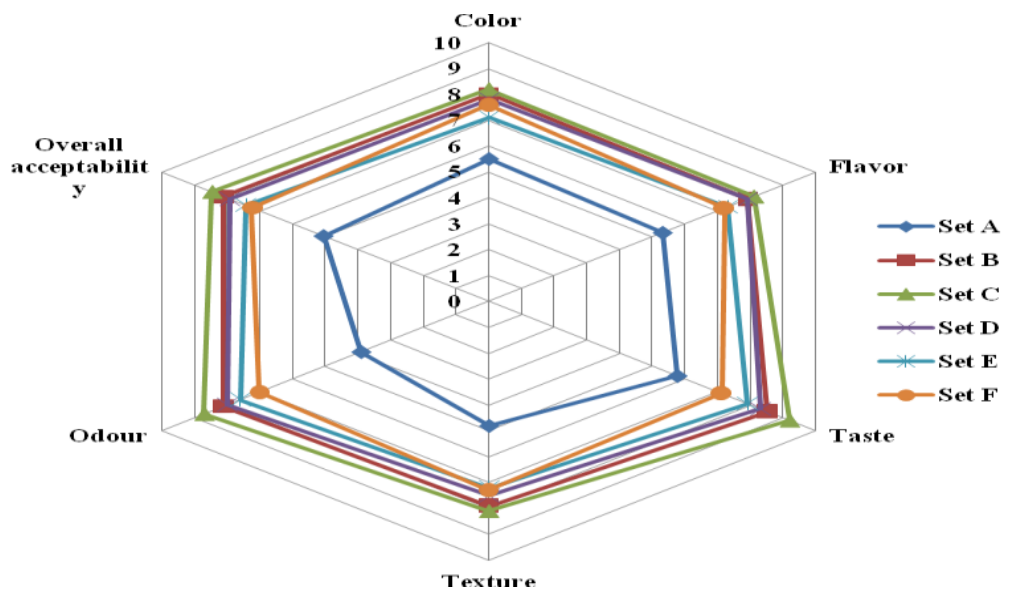

Fig.7 Comparison of crude and purified bacteriocin of Lactobacillus brevis SM6 with chemical preservative against Listeria monocytogenes to enhance shelf life of apricot RTS

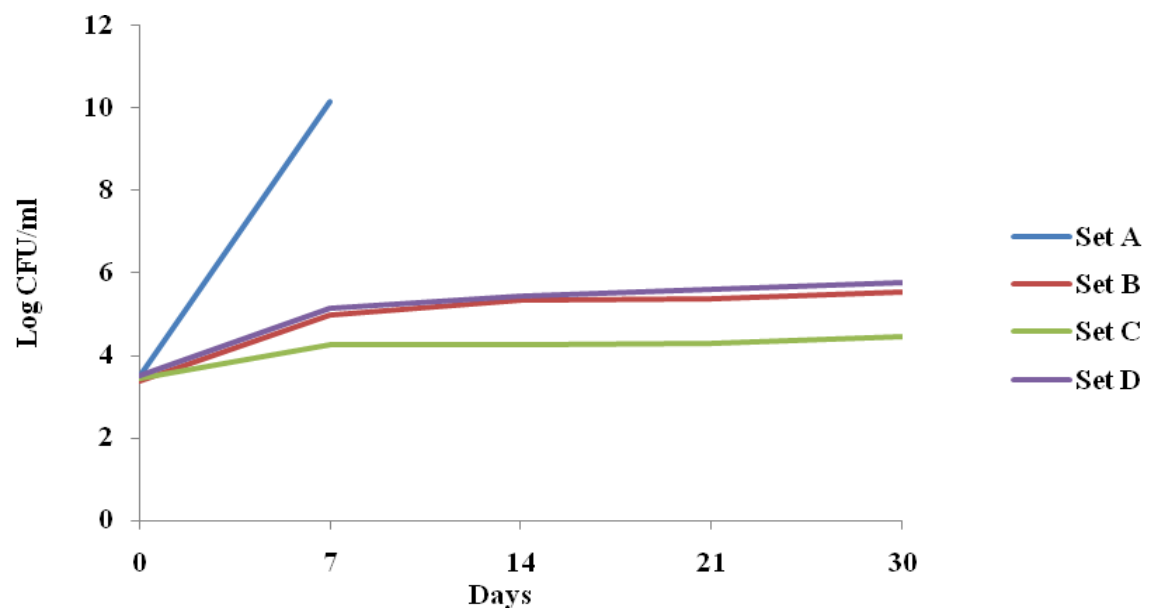


Fig.8 Comparison of bacteriocinogenic lactic acid bacteria Lactobacillus brevis SM6 against Listeria monocytogenes to enhance shelf life of apricot RTS

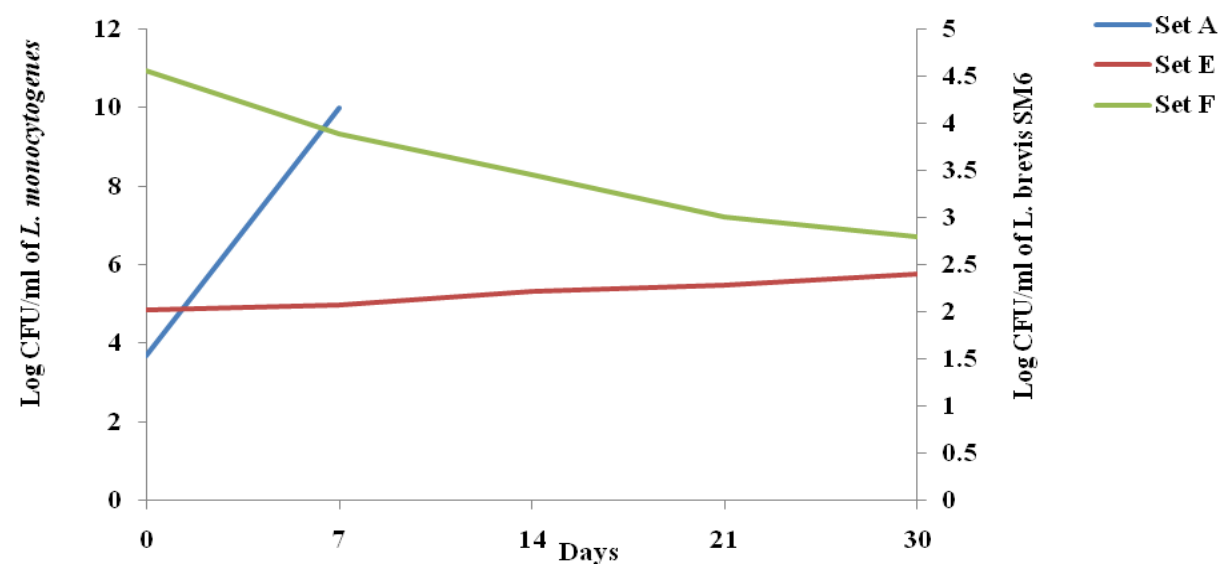

In conclusion, the bacteriocin Lactobacillus brevis SM6 has been found quite effective as compared to the chemical preservative and serve as a good candidate to extend the storage life of apricot RTS and apricot plum by preventing the growth of harmful spoilage causing pathogens.

\section{Acknowledgements}

The authors are very thankful to the Department of Environment, Science and Technology, H. P. Govt. for funding this study.

\section{References}

Amerine, M.A., Pangborn, R.M., Roessler, E.B., 1965. Principles of Sensory Evaluation of Food. Academic Press, New York. 602p.

AOAC., 1995. Approved methods of association of official analytical chemists. Washington D.C. U.S.A. 11th edition.

Belitz, H.D., Grosch, W., Schieberle, P., 2009. Food Chemistry. Fourth ed. Springer-Verlag Berlin Heidelberg. 1070p.

Brand, W., Cuvelier, M.E., Berset, C., 1995.
Use of a free radical method to evaluate antioxidant activity. Lebensmittel-Wissenschaft and Technologie. 28, 25-30.

Castro, J.K., Cerquera, N.E., Bonilla, E.P., $2017 . \quad$ Physicochemical characterization and sensory evaluation of banana pulp (Musa paradisiaca). Journal of Engineering andApplied Sciences.12, 423-428.

Dambalkar, V.S., Rudrawar, B.D., Poojari V.R., 2015. Study of physicochemical properties and sensory attributes of beetroot-orange RTS drink. International Journal of Science and Research4, 611-618.

Erdogan, I.O., Kartal, M., 2011. Insights into research on phytochemistry and biological activities of Prunus armeniaca. International Journal of Food Research 44, 1238-1243.

Gordeska, K., Czarnecka, M., Czarnecki, Z., 2007. Effect of prebiotic additives to carrot juice on the survivability of Lactobacillus and Bifidobacterium bacteria. Polish journal of food and nutrition sciences 57, 432-437.

Gupta, A., Sharma, N., 2017. Characterization of Potential Probiotic Lactic Acid Bacteria- Pediococcus acidilactici Ch2 Isolated from Chuli- A Traditional 
Apricot Product of Himalayan Region for the Production of Novel Bioactive Compounds with Special Therapeutic Properties. Journal of Food: Microbiology, Safety \& Hygiene 2, 1. Ogunbanwo, S.T., Okanlawon, B.M., 2006. Microbial and Sensory Changes During the Cold Storage of Chicken Meat Treated with Bacteriocin from Lactobacillus brevis OG1. Pakistan Journal of Nutrition 5, 601-605.

Pal, M., 2013. Food spoilage. Ph.D., Lecture Notes. Addis Ababa University, College of Veterinary Medicine, Debre Zeit, Ethiopia. pp.1-9.

Pal, M., 2014. Preservation of various foods. Ph.D., Lecture Notes. Addis Ababa University, College of Veterinary Medicine, Debre Zeit, Ethiopia. pp.111.

Raja, P., Wesley, R., Raj, A.A., Tiroutchelvamae, D., 2010 .Review on
: Bacteriocin and their Applications in Food Packaging and Safety. International Journal of Engineering Research, 3, 645-651.

Ranganna, S., 2009. Handbook of analysis and quality control for fruits and vegetable products. Second ed. Tata Mc Graw Hill Publication Co, New Delhi.1112p.

Ray, B., Miller, K.W., Jain, M.K., 2001. Bacteriocins of lactic acid bacteria: Current perspectives. Indian Journal of Microbiology 41, 01-21.

Sadasivam, S., Manickam, A., 1992. Biochemical Methods For Agricultural Sciences, Wiley Eastern Limited and Coimbatore: Tamil Nadu Agricultural University, New Delhi. India.

Sharma, N., Gautam, N., Sharma, H.K., 2009. Bacteriocin: Food preservative. In: Food Science and Technology. Nova Publications, New Delhi. pp. 137-167.

\section{How to cite this article:}

Archna Dharwal, Nivedita Sharma, Shakshi Sharma and Kanika Sharma. 2019. Biopreservation of Apricot pulp and Apricot Ready to Serve by using Bacteriocin of Lactobacillus brevis SM6 and their Comparison with Chemical Preservative. Int.J.Curr.Microbiol.App.Sci. 9(05): 34033419. doi: https://doi.org/10.20546/ijcmas.2020.905.405 